\title{
New methylene-bridged hexopyranosyl nucleoside modified oligonucleotides (BHNA): synthesis and biochemical studies
}

\author{
Chuanzheng Zhou and Jyoti Chattopadhyaya* \\ Department of Bioorganic Chemistry, Box 581, Biomedical Center, \\ Uppsala University, SE-751 23 Uppsala, Sweden \\ E-mail:jyoti@boc.uu
}

This paper is dedicated to Professor Harri Lönnberg on the occasion of his $60^{\text {th }}$ anniversary

\begin{abstract}
The hyper-constrained nucleoside, methylene-bridged hexopyranosyl nucleoside (BHNA) was incorporated into the antisnese oligonucleotides (AON), which show more preference for binding toward the complementary RNA $\left(T_{\mathrm{m}}\right.$ loss by ca $\left.5^{\circ} \mathrm{C}\right)$ than that with the complementary DNA $\left(T_{\mathrm{m}}\right.$ loss by $10^{\circ} \mathrm{C}$ ), vis-à-vis corresponding native duplex. The origin of reduction of $T_{m}$ of the duplexes formed by the BHNA incorporated AON and the complementary RNA or DNA was further investigated by thermal denaturation study with the single-mismatched DNA or RNA, CD spectroscopy, RNase $\mathrm{H}$ digestion study, as well as by molecular model building. These studies showed that the introduction of BHNA causes only a limited local conformational perturbation in the AON/RNA heteroduplex, whereas it affects the global conformation in the AON-DNA duplex. BHNA incorporated AONs also show improved stability in the human blood serum, which may prove to have some potential therapeutic application.
\end{abstract}

Keywords: Conformationally-constrained nucleotide, hexopyranosyl nucleotide, antisense oligonucleotides (AON), nuclease stability, molecular modeling

\section{Introduction}

Conformationally-constrained oligonucleotides have attracted considerable interest in the last two decades because they enable us to dictate specific conformational character in to the therapeutically interesting oligonucleotides, thereby allowing to steer their biological properties, as required in the antisense, siRNA or triplex strategy. ${ }^{1-3}$ The pentose-sugar moiety in natural nucleos $(t)$ ide is very flexible compared to those of the hexose-based oligos, and consequently can adopt a dynamic equilibrium of several sugar pseudorotamers. ${ }^{4,5}$ It has been however found that the North-type $\left(34^{\circ}>\mathrm{P}>-1^{\mathrm{o}}, \Phi_{\mathrm{m}}>30^{\circ}\right)$ or South-type $\left(194^{\circ}>\mathrm{P}>137^{\circ}, \Phi_{\mathrm{m}}>48^{\circ}\right)$ 
conformation determines the global conformation of DNA (A-form B-form or Z-form) or RNA (A-type), and consequently their physical, chemical and biological properties. ${ }^{6}$ We have shown that the purine-rich single-stranded native oligonucleotides ${ }^{7}$ can adopt a helical structures that are reminiscent of the native double-stranded counterpart. Appropriate modification of the sugar moiety of oligonucleotide can also potentially assist in their preorganization in to a helical form, and can improve its recognition to the target RNA and/or DNA, ${ }^{8}$ which is important in the antisense and siRNA technology. Sugar modifications, so far known, can be classified in to three major types: (1) The $2^{\prime}$-substituion with an electronegative group such as $-\mathrm{OMe}, \mathrm{F}, \mathrm{MOE}^{9}$ can drive the pentose sugar part adopting a North-type conformation, which, when introduced to the $\mathrm{AON}$, can induce the modified AON to have higher affinity to the target RNA (2$3^{\circ} \mathrm{C} /$ modification). (2) Covalent links between the $\mathrm{C} 2{ }^{\prime}$ and $\mathrm{C} 4{ }^{\prime}$ with alkyloxyl (LNA, ${ }^{10} \mathrm{ENA}^{11}$, ${ }^{12}$ ) or the carbocylic chain (carba-LNA ${ }^{13}$ and carba-ENA ${ }^{13,14}$ ), or by a covalent linkage between $\mathrm{C}^{\prime}$ ' and $\mathrm{C}^{\prime}$ (such as oxetane ${ }^{15}$ or azetidine ${ }^{16,17}$ types of constraints) result in to a conformationally-constrained North-type sugar. Oligonucleotides with these types of covalently constrained nucleosides can also potentially preorganize the single-stranded oligonucleotide in to a helical form, which, in turn, show much improved affinity toward complementary RNA (3$8^{\circ} \mathrm{C} /$ modification, with the exception of $\mathrm{C}^{\prime}$ and $\mathrm{C} 2^{\prime}$ constrained systems) as well as to $\mathrm{DNA}^{18}$; they also show improved resistance toward enzyme degradation. ${ }^{13,17}$ (3) The AONs produced by the replacement of the pentofuranosyl sugar with the hexopyranosyl sugar ${ }^{19}$ give thermodynamically stable duplexes with the target DNA or RNA. It is because, first, the sixmembered ring system adopt a rigid chair conformation, requiring a less negative entropy change during the duplex formation; and second, the interstrand phosphate distance in the six-membered pyranosyl-modified system is larger than in the natural nucleic acid duplexes giving a relatively less interstrand charge repulsion compared to the native counterpart. ${ }^{19}$ Many different types of pyranosyl modified nucleosides have been so far incorporated in to AONs, and their affinity toward complementary RNA or DNA, as well as the biochemical features have been studied by the groups of Herdewijn and Eschenmoser: ${ }^{2}$ AONs composed of homo-DNA (Figure 1) is almost linear, and not able to form duplexes with either RNA or DNA ${ }^{19,20}$, While $\mathrm{HNA}^{21,22}$, $\mathrm{CNA}^{23}$ and $\mathrm{CeNA}^{24-26}$ all have improved affinity toward RNA and show improved nuclease resistance compared to the native counterpart. Amongst these the CeNA modified AONs have attracted more attention because they are able to activate RNase $\mathrm{H}$, resulting in cleavage of the RNA strand in the AON-RNA heteroduplexes. 

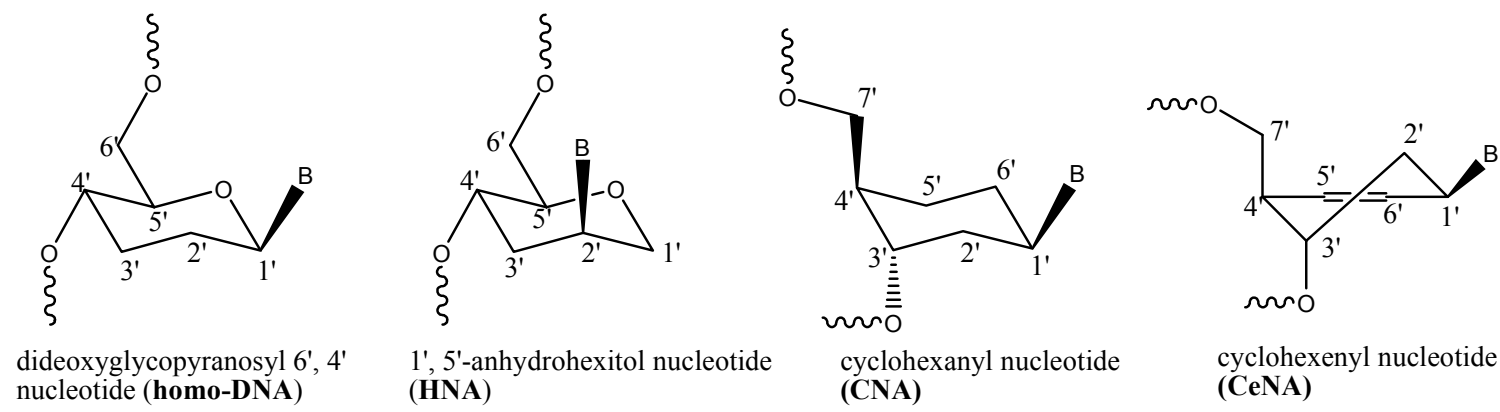

cyclohexenyl nucleotide (CeNA)

Figure 1. Structures of various pyranosyl nucleoside incorporated in to oligonucleotides.

Recently, during our effort to functionalize carbocyclic moiety of the carbocyclic-LNA ${ }^{13,27}$, we obtained one unusual bicyclo[2. 2.1] 2',5'- methylene-bridged hexose nucleoside $\mathbf{1}^{28}$ (BHNA, Scheme 1), which is a member of pyranose sugar family but is more rigid than any other reported constrained nucleoside. Here, we report the incorpoation of this hyper-constrained BHNA nucleoside into AON by the phosphoramidite-based DNA synthesis. We also report their affinity and specificity toward the complementary RNA and DNA, studied by UV melting experiment. We have also measured the CD spectra of their homo and heteroduplexes to evidence their global structure, which was also confirmed by RNase $\mathrm{H}$ foot printing experiment. It has also turned out that modification of the AON with the new hyper-modified pyranose-modified molecules, as in $\mathbf{1}$, greatly improve human blood serum stability in comparison with the native counterpart.

\section{Results}

\section{(A) Phosphoramidite synthesis}

During our effort to functionalize the carbocyclic moiety of the 5-membered carba-LNA ${ }^{13}$ through new synthetic routes ${ }^{27}$, we attempted to remove the 6'-hydroxyl group of $6^{\prime}$-hydroxy-6'methyl-carba-LNA ${ }^{27}$, prepared from $6^{\prime}$-hydroxy-carba-LNA ${ }^{27,28}$ : The synthetic route to compound $\mathbf{1}^{28}$ starts from $6^{\prime}$-hydroxyl-6'-methyl-carba-LNA ${ }^{27}$ (prepared by Chuanzheng Zhou in ref 27), which was obtained by the oxidation of 6'-hydroxy-carba-LNA (prepared by Munir Andaloussi in ref 27) followed by Grignard reaction to give $6^{\prime}$-hydroxy-6'-methyl-carba-LNA ${ }^{27}$. Unexpectedly, a unique stereospecifically rearranged compound 1 (Scheme 1) was obtained ${ }^{28}$ during the radical deoxygenation of $6^{\prime}$-methyloxalyl-6'-methyl-carba-LNA in addition to a diastereomeric mixture of $\mathrm{C}^{\prime}$ '-reduced products. ${ }^{27,28}$ It turned out that this radical rearrangement only takes place when the tertiary radical is formed from the 5-membered conformationallyconstrained 6'-methyloxalyl-6'-methyl-carba-LNA ${ }^{27}$. The synthetic implication and mechanistic studies of this unusual rearrangement will be published elsewhere. ${ }^{28}$ Compound $\mathbf{1}$ was spectroscopically pure and its structural determinations were based upon ${ }^{1} \mathrm{H}$ NMR, ${ }^{13} \mathrm{C}$ NMR, 
DEPT, COSY, ${ }^{1} \mathrm{H}^{13}{ }^{13} \mathrm{HMQC}$ and long range $\mathrm{HMBC}$ and $1 \mathrm{D}-\mathrm{nOe}$ experiments as well as by MALDI-TOF mass spectrometry (see supporting information).

Compound 1 was debenzylated using $20 \% \mathrm{Pd}(\mathrm{OH})_{2} / \mathrm{C}$ and ammonium formate under reflux in methanol for $4 \mathrm{~h}$, followed by 5'-dimethoxytritylation to give 2 (two step 78\%), which was 3'phosphitylated to give the phosphoramidite 3 using standard conditions. ${ }^{29}$ The ${ }^{31} \mathrm{P} \mathrm{NMR}$ spectrum of compound 3 showed that this phosphoramidite was pure (Figure 2), hence was used for oligo-DNA synthesis directly.

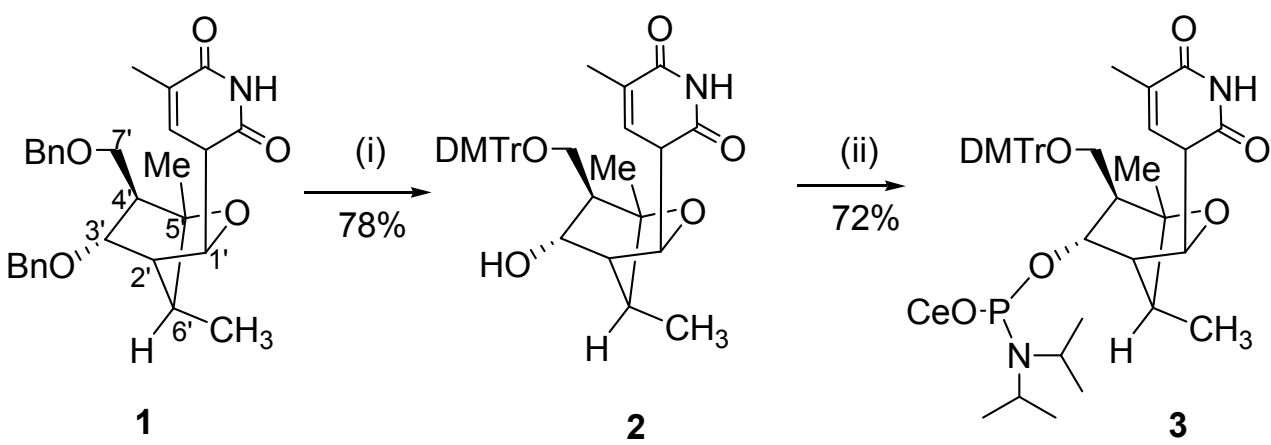

Scheme 1. Reagents and conditions: (i) a) $20 \% \mathrm{Pd}(\mathrm{OH})_{2} / \mathrm{C}$, Ammonium Formate, dry methanol, reflux, $3 \mathrm{~h}$; b) DMTr-Cl, dry pyridine, overnight; (ii) 2-cyanoethyl N,Ndiisopropylphosphoramidochloridite, DIPEA, dry THF, $2 \mathrm{~h}$.

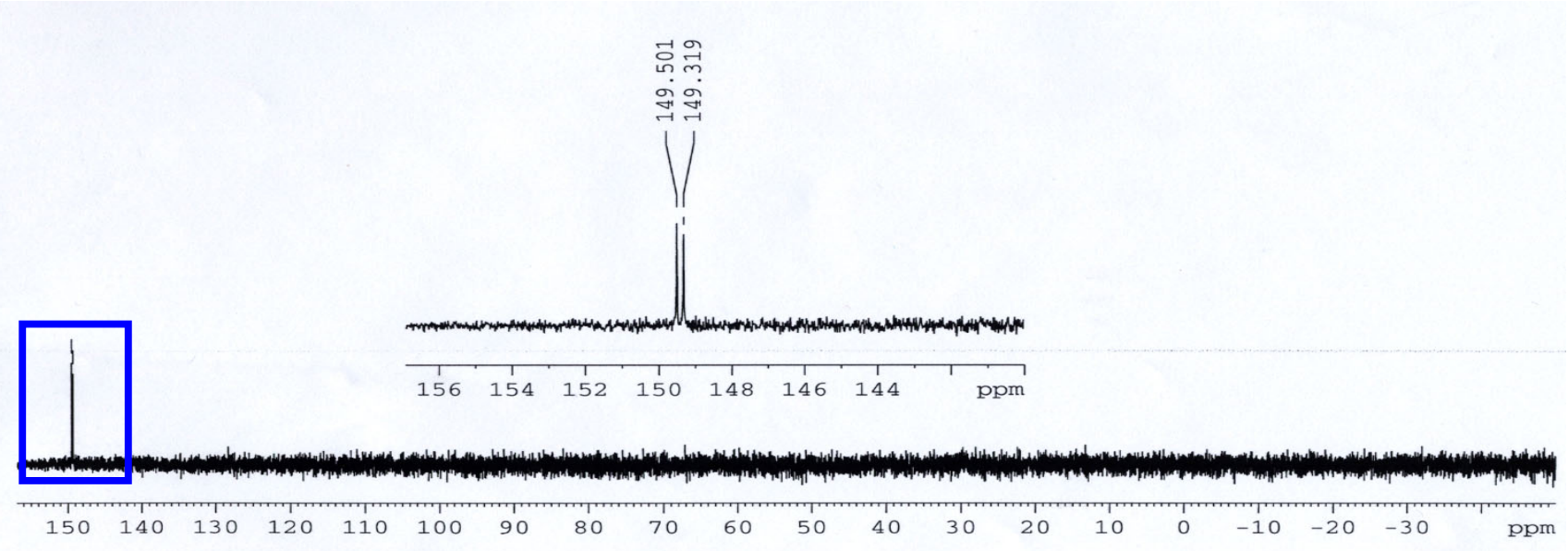

Figure 2. ${ }^{31} \mathrm{P}$ NMR spectrum of phosphoramidite 3. The region inside the blue frame is expanded and shown in the middle of the figure to evidence the purity.

\section{(B) Synthesis and thermal denaturation studies of BHNA incorporated AONs}

The phosphoramidite 3 was incorporated into a 15 mer DNA sequence by solid supported DNA synthesis protocol on Applied Biosystems 392 RNA/DNA synthesizer. Standard DNA synthesis cycle $\left(1 \mu \mathrm{mol}\right.$ scale) and common reagents ${ }^{29}$ were used except for incorporating modified 
nucleotides 3 by using a coupling time of 10 minutes. Cleavage of oligos from the support and deprotection was carried out just by treating the solid support with $33 \%$ aqueous ammonia at room temperature for $12 \mathrm{~h}$. The fully-deprotected AONs were then purified by $20 \%$ denatured PAGE.

The selected 15mer DNA sequence is targeted to the coding region of SV40 large T antigen. ${ }^{30}$ Four sequences were synthesized and each sequence has single modification of BHNA but at different sites of the 15 mer DNA sequence. The sequences and modification position are shown in Table 1. The integrity of AONs was corroborated by MALDI-TOF mass measurement (see Table 1).

The affinity of AONs 2-5 toward their complementary strands, DNA or RNA, were evaluated by UV melting experiments (Table 1). The melting temperatures $\left(T_{\mathrm{m}}\right)$ of duplex between native AON 1 and complementary DNA and RNA were $45.5^{\circ} \mathrm{C}$ and $44.7^{\circ} \mathrm{C}$, respectively. The $T_{\mathrm{m}} \mathrm{s}$ of AONs 2-5/DNA duplexes were $5.8-11.5^{\circ} \mathrm{C}$ lower than the native counterpart AON 1/ DNA. The terminal modification in the sequence AON 2 showed however relatively less $T_{\mathrm{m}}$ decrease $\left(-5.8^{\circ} \mathrm{C}\right)$ compared to the modification introduced in the middle of the sequences, AONs 3-5 (-10 to $-11{ }^{\circ} \mathrm{C}$ decrease). This sequence-dependent $T_{\mathrm{m}}$ decrease suggests the BHNA probably caused a global conformational change in the AON/DNA duplex.

BHNA also destabilized the AON/RNA duplex, but this effect is much less than in the AON/DNA duplexes, in view of the fact AONs 2-5/RNA heteroduplexes showed only $T_{\mathrm{m}}$ decrease of -4.3 to $-5.5^{\circ} \mathrm{C}$. Moreover, the middle-modified sequences AONs 3-5 showed a more moderate reduction of $T_{\mathrm{m}}\left(-4.1\right.$ to $\left.-4.3^{\circ} \mathrm{C}\right)$ compared to the terminal modified sequence AON 2 . These observations suggest the BHNA only cause local structural perturbation in the AON/RNA duplexes, which means that it could be still be a good substrate for RNase H digestion.

In order to validate this hypothesis that BHNA only introduced a local conformational heterogeneity in AON/RNA hybrid duplex, AON 5 was used to target RNAs 2-4 (Table 2) which have one mismatch just opposite the BHNA. The $T_{\mathrm{m}}$ values of duplexes of AON 5/RNA 2, AON 5/RNA 3, AON 5/RNA 4 are $-6.5,-10.6,-8.9^{\circ} \mathrm{C}$ lower respectively than fully-matched duplex AON 5/RNA 1, which is very similar to the native counterpart AON 1, in that AON 1/RNA 2, AON 1/RNA 3, AON 1/RNA 4 showed $T_{\mathrm{m}}$ decrease $-2.9,-11.5,-9.2^{\circ} \mathrm{C}$ respectively than fullymatched duplex AON 1/RNA 1. This observation suggested that 1-thyminyl moiety of BHNA can base-pair well with the opposite complementary nucleobase moiety in the AON/RNA hybrid, and confirmed that BHNA can only cause local perturbation in the AON/RNA duplex. 
Table 1. Thermal Denaturation $\left(T_{\mathrm{m}}\right)$ of native and modified AONs in the duplexes with complementary RNA or DNA ${ }^{\mathrm{a}}$

\begin{tabular}{|c|c|c|c|c|c|c|c|}
\hline \multirow{3}{*}{ Entry } & \multirow{3}{*}{ Sequence } & \multicolumn{2}{|l|}{$(\mathrm{MH})^{+}$} & \multicolumn{4}{|c|}{$T_{\mathrm{m}}\left({ }^{\circ} \mathrm{C}\right)$} \\
\hline & & \multirow{2}{*}{ Calc. } & \multirow{2}{*}{ Found } & \multicolumn{2}{|c|}{ With RNA } & \multicolumn{2}{|c|}{ With DNA } \\
\hline & & & & $T_{\mathrm{m}}$ & $\Delta T_{\mathrm{m}}$ & $T_{\mathrm{m}}$ & $\Delta T_{\mathrm{m}}^{*}$ \\
\hline AON 1 & $3^{\prime}-d(\mathrm{CTT}$ CTT TTT TAC TTC) & 4448.7 & 4449.7 & 44.7 & & 45.5 & \\
\hline AON 2 & 3'-d(CTT CTT TTT TAC TTC) & 4502.7 & 4503.0 & 39.2 & -5.5 & 39.7 & -5.8 \\
\hline AON 3 & $3^{\prime}-\mathrm{d}$ (CTT CTT TTT TAC TTC) & 4502.7 & 4503.1 & 40.6 & -4.1 & 35.2 & -10.3 \\
\hline AON 4 & $3^{\prime}-\mathrm{d}(\mathrm{CTT}$ CTT TTT TAC TTC) & 4502.7 & 4502.8 & 40.4 & -4.3 & 34.0 & -11.5 \\
\hline AON 5 & $3^{\prime}-d($ CTT CTT TTT TAC TTC) & 4502.7 & 4503.0 & 40.4 & -4.3 & 35.0 & -10.5 \\
\hline
\end{tabular}

${ }^{\mathrm{a}} T_{\mathrm{m}}$ values measured as the maximum of the first derivative of the melting curve (A260 vs temperature) in medium salt buffer $(60 \mathrm{mM}$ Tris- $\mathrm{HCl}$ at $\mathrm{pH} 7.5,60 \mathrm{mM} \mathrm{KCl}, 0.8 \mathrm{mM} \mathrm{MgCl}$ ) with temperature range 20 to $70{ }^{\circ} \mathrm{C}$ using $1 \mu \mathrm{M}$ concentrations of the two complementary strands. $\Delta T_{\mathrm{m}}: T_{\mathrm{m}}$ relative to RNA compliment; $\Delta T_{\mathrm{m}}{ }^{*}: T_{\mathrm{m}}$ relative to DNA compliment.

Table 2. $T_{\mathrm{m}}\left({ }^{\circ} \mathrm{C}\right)$ of AON 1 or AON 5 in the duplexes with complementary RNA with or without one base mismatch. ${ }^{\mathrm{a}}$

\begin{tabular}{|c|c|c|c|c|}
\hline & \multicolumn{4}{|c|}{ Complementary RNA : 5'-r(GAA GAA AAA XUG AAG) } \\
\hline & $\begin{array}{l}\mathbf{X}=\mathrm{A}(\mathbf{R N A} \\
\mathbf{1 , p a i r e d})\end{array}$ & G(RNA 2) & C(RNA 3) & U(RNA 4) \\
\hline AON 1 & 44.7 & $41.8(-2.9)^{b}$ & $33.2(-11.5)^{b}$ & $35.5(-9.2)^{b}$ \\
\hline AON 5 & 40.4 & $33.9(-6.5)^{b}$ & $29.8(-10.6)^{b}$ & $31.5(-8.9)^{b}$ \\
\hline
\end{tabular}

${ }^{\mathrm{a}}$ medium salt buffer is shown in footnote of Table $1 .{ }^{\mathrm{b}}$ The value in parentheses is $\Delta \mathrm{T}_{\mathrm{m}}$ which is the difference between mismatched and matched duplexes.

(C) Helical structure of the modified oligonucleotide duplex with DNA and RNA

CD spectroscopy was used to further qualitatively illustrate the nature of helical conformation of AON/DNA vis-a-vis AON/RNA duplexes (Figure 3). Since BHNA causes serious reduction of $T_{\mathrm{m}}$ (ca $10^{\circ} \mathrm{C}$ reduction for AON/DNA and ca $5^{\circ} \mathrm{C}$ reduction for AON/RNA) suggest that AON/DNA and AON/RNA conformations for these modified duplexes are likely to be different. It is noteworthy that this reduction of $T_{\mathrm{m}}$ is more marked for the AON/DNA duplexes than for the AON/RNA duplexes. Both AON 2/RNA and AON 5/RNA exhibited CD spectra intermediate between the native A-type RNA/RNA and B-type DNA/DNA duplexes, mimicking the natural AON 1/RNA hybrid duplex, which confirmed again that BHNA did not cause much conformational perturbation in AON/RNA duplex compared to AON/DNA duplex. On the contrary, the positive Cotton bands for AON 2/DNA and AON 5/DNA, $279 \mathrm{~nm}$ and $278 \mathrm{~nm}$ respectively, are blue shifted, and are more intense than the native AON 1/DNA duplex $(281 \mathrm{~nm})$. This result suggests that a single modification of BHNA in AON can modulate the 
AON/DNA duplex conformation beyond alteration of the local geometry, it has more global impact in terms of dictating conformational changes than that of the AON/RNA hybrid duplex. Thus the above CD observation actually supports the conclusion obtained form the $T_{\mathrm{m}}$ study, in that the conformational perturbation imparted by BHNA in AON/RNA is relatively local, while in AON/DNA is much more pronounced and affects the structure of the duplex more globally.

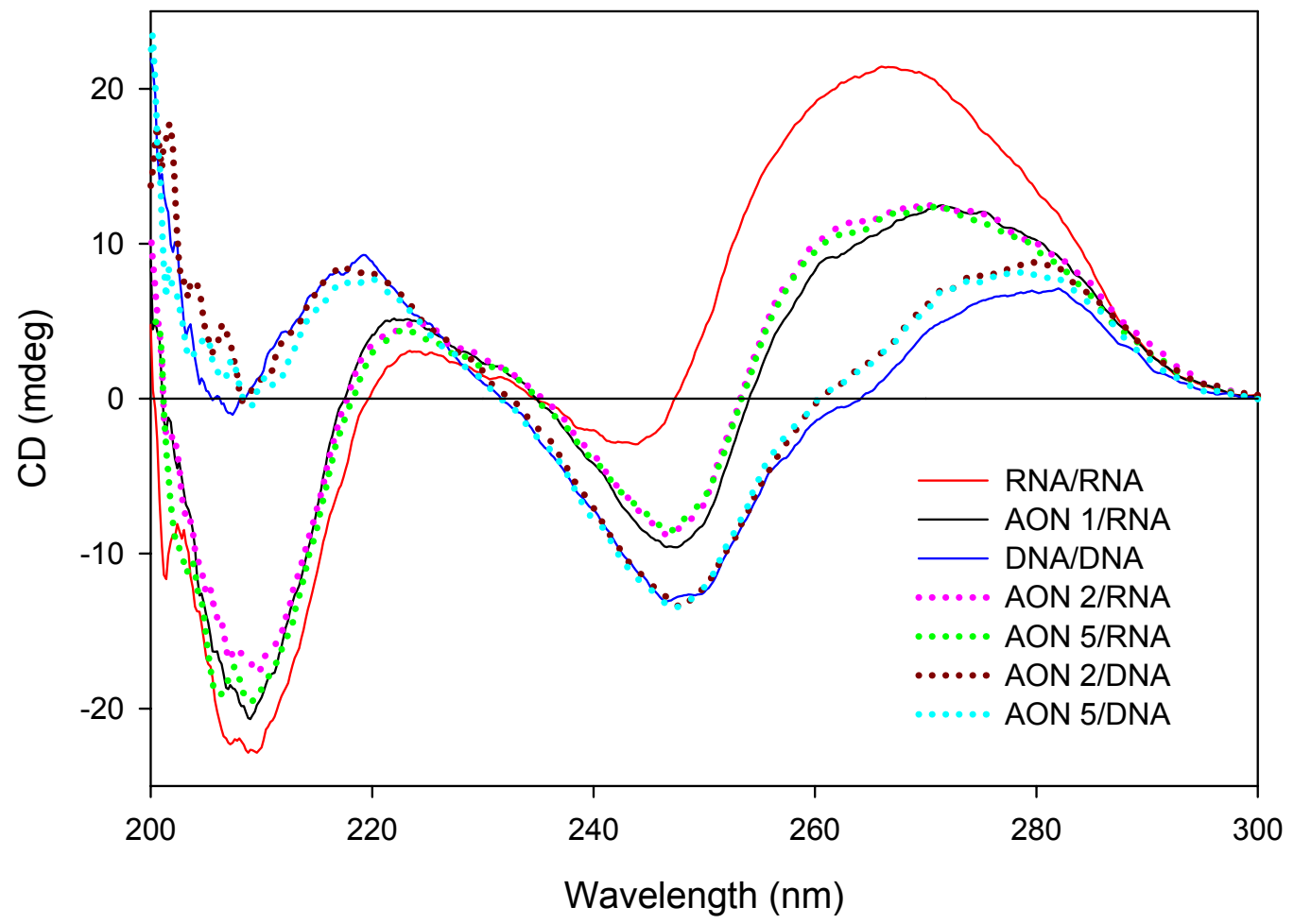

Figure 3. The CD spectra of duplexes formed by AONs $\mathbf{1 / 2 / 5}$ with the complementary RNA or DNA. For comparison, typical B-and A-type spectra are also presented for native DNA/DNA duplex formed by the native AON 1 with complementary DNA. Native RNA/RNA duplex shown is formed by 3'-r(CUU CUU UUU UAC UUC) with complementary RNA. The CD spectra were measured in the same buffer as used for UV melting experiment (Table 1) at $20^{\circ} \mathrm{C}$. The total concentration is $10 \mu \mathrm{M}$.

\section{(D) RNase $\mathrm{H}$ footprinting AON/RNA duplex}

Since the AONs 2-5 can form stable hybrid duplex with complementary RNA, which have comparable conformation as that of the native AON 1/RNA, the AONs 2-5/RNA should be good substrate for RNase $\mathrm{H}$ and cleave the RNA strand selectively. Here, native AON 1 and modified AONs 2-5 were hybridized with $5^{\prime}-{ }^{32} \mathrm{P}$ labeled 15 mer complementary RNA at $21{ }^{\circ} \mathrm{C}$, and incubated with Escherichia coli RNase H1. Aliquots were taken after 3, 7, 15, 25, 40, 60 min, analyzed by PAGE, and results are shown in Figure 4A.

The cleavage rates were determined by densitometric quantification of gels and subsequently by plotting the uncleaved RNA fraction as a function of time (Figure 4B). The reaction rates

were obtained by fitting the degradation curves to single-exponential decay functions. ${ }^{31}$ The 
relative cleavage rates for AONs 2-5/RNA duplexes were found to be very similar to that of native counterpart (Figure 4C).

Cleavage pattern of AONs 1-5/RNA hybrids was also compared to shed light as to how much local structure was disrupted by the BHNA modification (Figure 4D). In the native hybrid duplex AON 1/RNA, the whole region from A5 to U11 was accessible for RNase $\mathrm{H}$ promoted cleavage with a slight preference at the 3'-phosphate of A8. In the case of AON 2, the modification opposite A3 of the complementary RNA made the region A3-A7 inaccessible for RNase $\mathrm{H}$ cleavage while A8 remain the major cleavage site. For AON 3, the modification opposite A6 of RNA result in loss of RNase H promoted cleavage in the region A6-A10. Instead, U11 and A13 appeared as the major cleavage sites. The AON 4/RNA hybrid duplex also show unique cleavage pattern toward RNase $\mathrm{H}$ incubation. The region of A8-G12 affected by the modification is not accessible for cleavage and the major cleavage sites were shifted to A6 and A13. As expected, the modification opposite A10 of the complementary RNA, as in the AON 5, result in the absence of any cleavage sites in the region A10-A14, while regaining all the cleavage sites from A5 to A8 present in the native hybrid duplex, and A8 remain the major cleavage site. So cleavage activity of RNase $\mathrm{H}$ was suppressed with a region, about 5-6 basepairs long, towards the 3'-end of the RNA in the AON/RNA hybrid, starting from the base opposite the modified $\underline{\mathbf{T}}$ nucleotide in the AON strand. The RNase $\mathrm{H}$ promoted cleavage has a preference at the middle site A8 of the RNA strand. If A8 is included within the modification region (a stretch of 5 basepairs), the major cleavage site just shift to the edges of the modification region.

\section{(E) Blood serum stability of BHNA incorporated AONs}

The stability of AONs toward various exo- and endonucleases is necessary in order to develop therapeutic oligonucleotides. Here, the stability of BHNA modified oligonucleotides in human blood serum was studied and compared with native counterpart. Since human blood serum is mainly composed of $3^{\prime}$ - exonuclease, ${ }^{32}$ the oligonucleotide with a single BHNA modification at position 3 from 3'-end (AON 2) was choosen to test the BHNA's stability in human blood serum. Thus, the AON 1 and AON $2\left({ }^{32} \mathrm{P}\right.$-labeled at the 5'-end) were incubated with human blood serum (male, type $\mathrm{AB}$ ) at $21^{\circ} \mathrm{C}$. Aliquots were taken out at specific time points and analyzed by $20 \%$ denatured PAGE. The gel pictures after autoradiography are shown in Figure 5.

The native AON 1 is not stable in human blood serum and was completely degraded in $4 \mathrm{~h}$. For modified AON 2, the last nucleotide $\mathrm{dC}$ was first removed to give the $14 \mathrm{mer}$ as the predominant fragment in $1 \mathrm{~h}$. The 14 mer fragment thus produced was found to be resistant to nucleases up to $24 \mathrm{~h}$. In view of the presence of alkaline phosphatase in blood serum which removed the $5^{\prime}$-end ${ }^{32} \mathrm{P}$-label gradually, the BHNA incorporated AON should be even more stable than we observed here $(24 \mathrm{~h})$. Thus the work described show that the 3 '-phosphodiester linkage of BHNA modified AONs is relatively more resistant to nucleases digestion compared to that of native AONs, and the BHNA integrated oligonucleotides could be have potential therapeutic application in the future. 
(A)

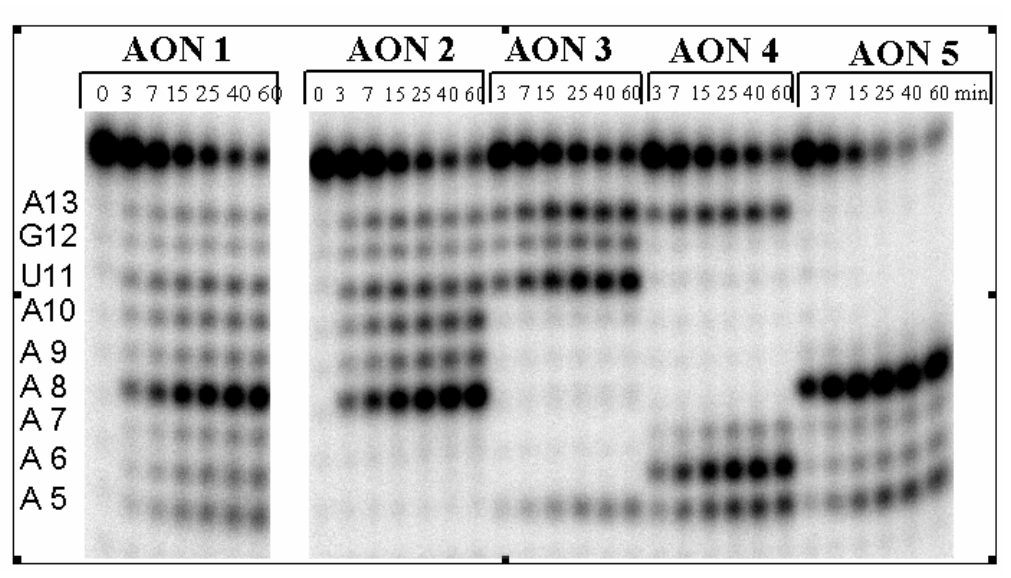

(B)

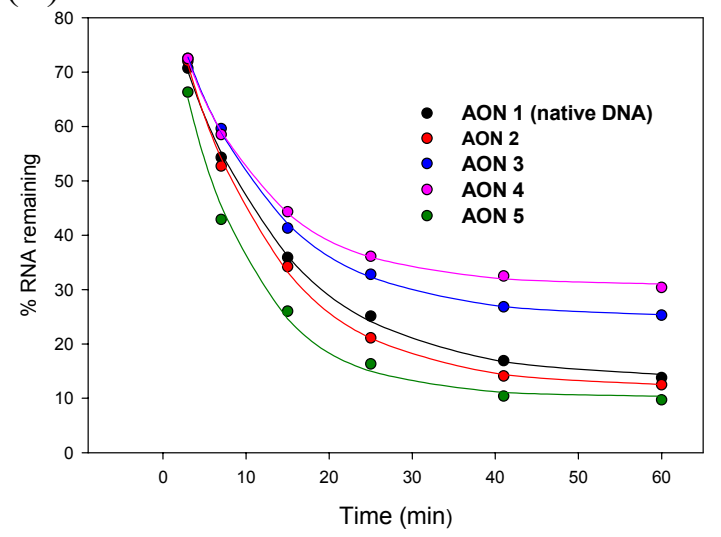

(C)

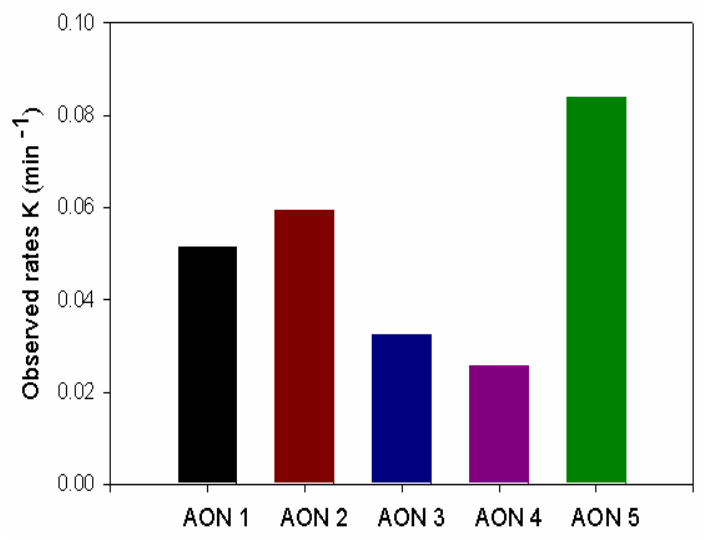

(D)

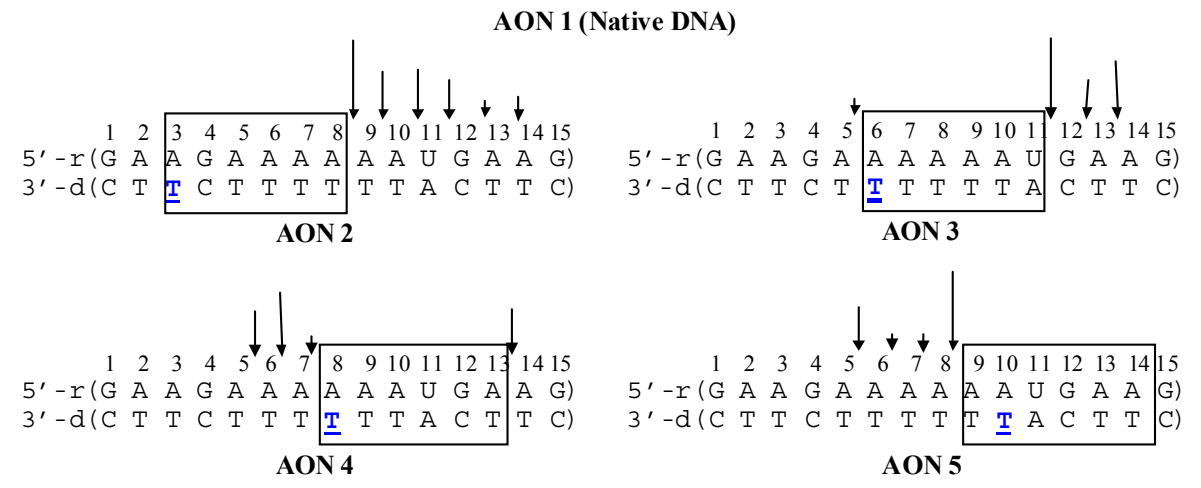

Figure 4. (A) Autoradiograms of $20 \%$ denaturing PAGE, showing the cleavage kinetics of 5'${ }^{32}$ P-labeled target RNA by E. coli RNase H1 in AON/RNA hybrids after 3, 7, 15, 25, 40 and $60 \mathrm{~min}$ of incubation. Conditions of cleavage reactions: RNA $(0.1 \mu \mathrm{M}$, specific activity 80000 $\mathrm{cpm})$ and $\mathrm{AON}(2 \mu \mathrm{M})$ in buffer containing $20 \mathrm{mM}$ Tris- $\mathrm{HCl}(\mathrm{pH} 7.5), 20 \mathrm{mM} \mathrm{KCl}, 10 \mathrm{mM}$ $\mathrm{MgCl}_{2}, 0.1 \mathrm{mM}$ EDTA, and $0.1 \mathrm{mM}$ DTT at $21{ }^{\circ} \mathrm{C}, 0.08 \mathrm{U}$ E. coli RNase H1, total reaction volume $30 \mu \mathrm{L}$. (B) Kinetics of cleavage. The target RNA remaining is densitometrically evaluated and plotted as a function of time. (C) Bar plot shows the comparative cleavage rates of 
target RNA in different AON/RNA hybrids. (D) RNase H 1 cleavage pattern of AON 1-5/RNA hybids. Vertical arrows show the cleavage sites, with the relative length of an arrow showing the extent of the cleavage.

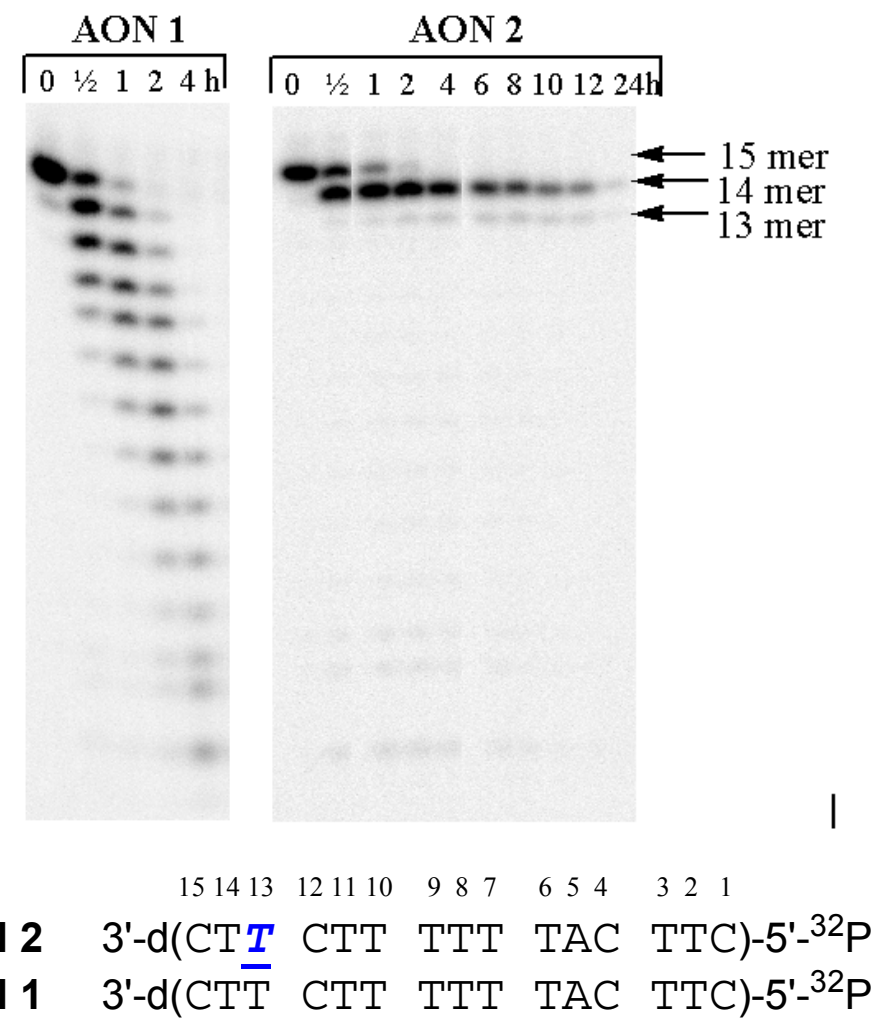

Figure 5. Autoradiograms of $20 \%$ denatured PAGE showing the stability of $5{ }^{\prime}-{ }^{32} \mathrm{P}$-labeled AON 1 and AON 2 in human blood serum. Time points are taken after 0, 1/2, 1, 2, 4, 6, 8, 10, 12, 24h of incubation at $21^{\circ} \mathrm{C}$ (see Experimental section for details). $\underline{T}$ represents BHNA.

\section{Discussion}

Mismatch study suggests that BHNA are well basepaired with the opposite nucleobase in the AON/RNA hybrid duplex. The CD spectra also showed the BHNA modified AON/RNA adopt a conformation comparable to that of the native AON/RNA duplex, which means that BHNA can only cause limited local distortion in the AON/RNA duplex, which was also confirmed by the molecular model of AON/RNA duplex. The model of A-type duplex d(TTT)/r(AAA) and $\mathrm{d}(\mathrm{TTT}) / \mathrm{r}(\mathrm{AAA})$ obtained by Amber geometry optimization are shown in Figure 6D-F. Overlaying the model of native d(TTT)/r(AAA) with that of d(TTT)/ r(AAA) has shown that in the A-type duplex (although BHNA modification in $\mathrm{d}(\mathrm{T} \underline{\mathrm{T}}$ ) changes the conformation of backbone to some extent) the base of BHNA still stacks between neighboring nucleobases and is coplanar with the complementary base of the opposite strand, forming perfect hydrogen bonds. 
Thus, the limited local perturbation imparted by BHNA may contribute, but only partly, to the $T_{\mathrm{m}}$ loss $\left(\mathrm{ca}-5^{\circ} \mathrm{C}\right)$ in AON/RNA duplex. Another possible reason for this big $T_{\mathrm{m}}$ loss may be the hydrophobic character of the BHNA. Extensive hydration of individual hydrogen bond acceptors and donors in oligoucleotides generally increase thermodynamic stability of the corresponding duplexes. The unusually extensive hydration pattern in LNA or 2'-MOE integrated duplex potentially contribute substantially to the stability of the duplex. In the RNA RNA or DNA $\cdot$ RNA duplex, a water network can be formed in the minor groove by interaction with the 2'-OH, with the heterobase atom, O3', and O5', O4', phosphate anion oxygen of adjacent nucleotides at the $3^{\prime}$ end directly or through water bridge. As shown in the model, in the d(TIT)/ r(AAA) duplex, the hydrophobic methylene bridge and two methyl groups of BHNA are located in the minor groove and would seriously disturb the hydration network in the minor groove. The hydrogen bonding network around the sugar-phosphate backbone can also be disturbed considerably. It is quite likely that this change of the hydrogen bonding pattern maybe the major reason for the unusual $T_{\mathrm{m}}$ loss $\left(\mathrm{ca}-5^{\circ} \mathrm{C}\right)$ in AON/RNA.

Comparing the model of B-type duplex d(TTT)/d(AAA) and d(T $\underline{T}$ ) $/ \mathrm{d}(\mathrm{AAA})$ (Figures 6AC) show that the modification of BHNA lead to a much more significant conformational perturbation in AON/DNA duplex. The base of BHNA points at the major groove, and stereochemically not favored to form any hydrogen bond with the base of the opposite nucleotide. This perturbation stretches along the phosphate backbone and affect the conformation of neighboring nucleotides. This model offers a plausible explanation why BHNA causes a serious $T_{\mathrm{m}}\left(\mathrm{ca}-10^{\circ} \mathrm{C}\right)$ loss and global conformational change in AON/DNA duplex compared to the native DNA/DNA duplex.

The BHNA integrated AON/RNA duplex elicits RNase $\mathrm{H}$, but no RNA cleavage can however be detected in a five to six nucleotide gap starting from the corresponding 3 '-end of the modification site in the AON strand. This is very similar to what we have observed earlier with other North-type conformationally constrained systems such as oxetane ${ }^{15}$ azitidine $^{16,17}$ or azaENA $^{12}$ based AONs/RNA duplexes. This can be attributed to the local conformational change from DNA $\bullet$ RNA type to the RNA $\cdot$ RNA type conformation, which is not a substrate to RNase $\mathrm{H}$. This local conformational change for a stretch of 5-6 nucleotides is however not detectable either by CD spectra or by the molecular model. Both of them show that the modified-AON/RNA adopt a perfect conformation similar to that of the native DNA/RNA duplex. 
(A)

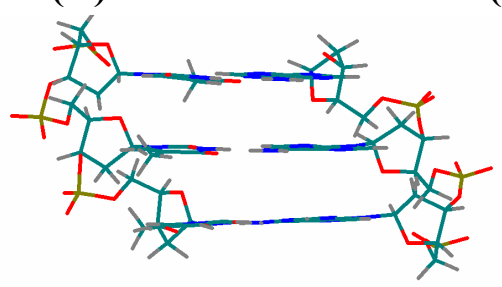

(D)

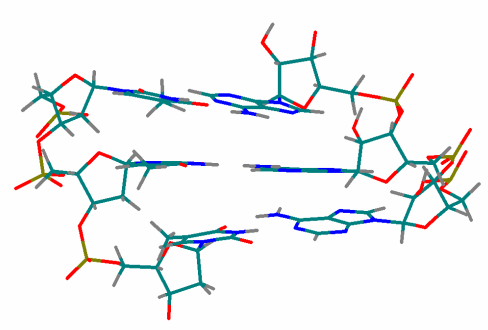

(B)

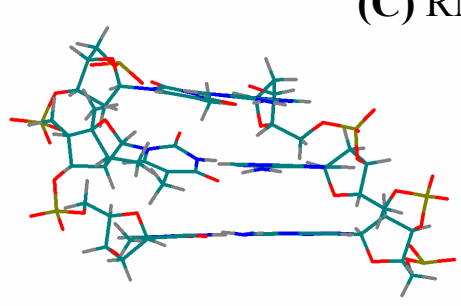

(C) $\mathrm{RMSD}=1.05 \AA$ for the middle base pair

(E)

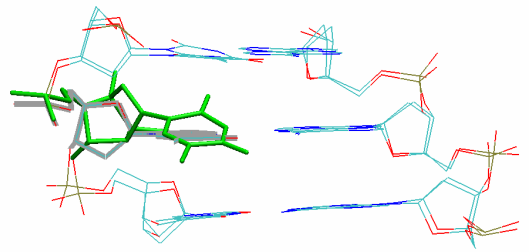

(F) $\mathrm{RMSD}=0.275 \AA$ for the middle base pair

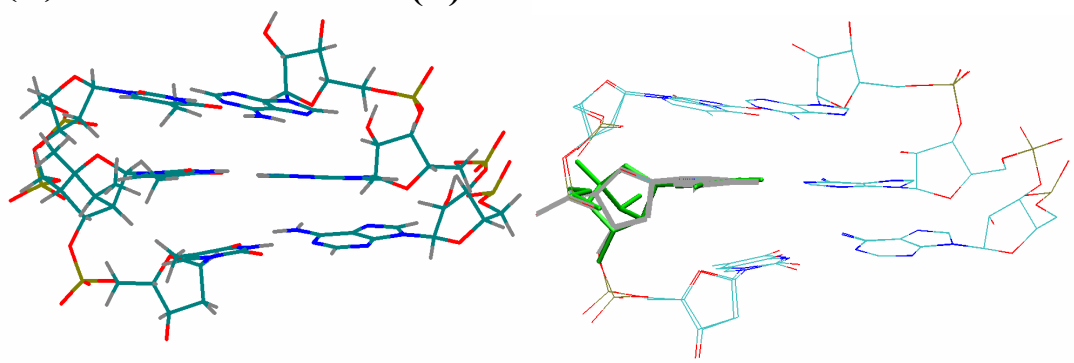

Figure 6. Model of B-type d(TTT)/d(AAA) duplex (panel A) and d(TTT)/d(AAA) (panel B), Model of A-type d(TTT)/r(AAA) duplex (panel D) and d(TTT)/r(AAA) (panel E). Panel C shows an overlay structures in panels $\mathrm{A}$ and $\mathrm{B}$ (RMSD difference $\approx 1.05 \AA$ ). Panel $\mathrm{F}$ shows an overlay structures in panels $\mathrm{D}$ and $\mathrm{E}$ (RMSD difference $\approx 0.029)$. $\underline{\mathrm{T}}$ represents BHNA.

\section{Conclusions and Implications}

(1) The hyper-constrained nucleoside, methylene-bridged hexose (BHNA) was purified and incorporated into antisnese oligonucleotides (AON).

(2) The BHNA incorporated AON show preference toward complementary RNA than complementary DNA, although both AON/RNA $\left(\mathrm{ca}-5^{\circ} \mathrm{C}\right.$ ) and AON/DNA (ca $-10^{\circ} \mathrm{C}$ ) duplex have lower $T_{\mathrm{m}}$ compared to the native DNA/RNA and DNA/DNA duplex.

(3) Thermal denaturation study with mismatch and CD spectra of AON/RNA suggest BHNA can only cause limited local conformational perturbation in AON/RNA duplex, which was also confirmed by RNase $\mathrm{H}$ digestion.

(4) BHNA causes a global conformation perturbation, whereas its hydrophobic character contributing to the serious $T_{\mathrm{m}}$ loss in AON/DNA duplex.

(5) BHNA incorporated AONS have much improved stability in human blood serum and so could have potential therapeutic application in the future. 


\section{Experimental Section}

General Procedures. Chromatographic separations were performed on Merck G60 silica gel. Thin layer chromatography (TLC) was performed on Merck pre-coated silica gel 60 F254 glassbacked plates. ${ }^{1} \mathrm{H}$ NMR spectra were recorded at 500 and $600 \mathrm{MHz}$ respectively, using TMS $(0.0 \mathrm{ppm})$ as internal standards. ${ }^{13} \mathrm{C}$ NMR spectra were recorded at $125.7 \mathrm{MHz}$ and $150.9 \mathrm{MHz}$ respectively, using the central peak of $\mathrm{CDCl} 3(76.9 \mathrm{ppm})$ as an internal standard. ${ }^{31} \mathrm{P}$ NMR spectra were recorded at $202.5 \mathrm{MHz}$. Chemical shifts ( $\delta$ scale) are reported in ppm. The nucleobase of the $\mathrm{A}, \mathrm{C}$ have been protected using fast deprotecting phenoxyacetyl (PAC) and acetyl (AC) groups, respectively. MALDI-TOF mass spectra were recorded in positive ion mode for oligonucleotides and other compounds. All compounds were spectroscopically pure and their structural determinations were based upon ${ }^{1} \mathrm{H}$ NMR, ${ }^{13} \mathrm{C}$ NMR, COSY, HETCORR experiments as well as by MALDI-TOF mass spectrometry.

(1S, 3R, 4R, 5S, 6R, 7S)-5-Benzyloxy-6-benzyloxmethyl-1, 7-dimethyl-3-(thymin-1-yl)-2oxa-bicyclo[2.2.1]heptane (1). (compound 1 was prepared by a two-step procedure from $6^{\prime}$ hydroxyl-6'-methyl-carba-LNA ${ }^{27}$ by radical deoxygenation at $\left.\mathrm{C}^{2}{ }^{28}\right){ }^{1} \mathrm{H} \mathrm{NMR}\left(500 \mathrm{MHz}, \mathrm{CDCl}_{3}\right)$ $\delta$ : $8.23\left(1 \mathrm{H}\right.$, brs, H3), 7.35-7.25 (m, 11H), $5.52\left(\mathrm{~d}, J_{1}{ }^{\prime}, 2,=3.1 \mathrm{~Hz}, \mathrm{H} 1^{\prime}\right), 4.57-4.45(\mathrm{~m}, 4 \mathrm{H}$, $\mathrm{BnC}_{2}$ ), 3.58 (dd, $\left.J_{7^{\prime}, 4^{\prime}}=6.9 \mathrm{~Hz}, J_{\mathrm{gem}}=9.5 \mathrm{~Hz}, 1 \mathrm{H}, \mathrm{H} 7^{\prime}\right), 3.36$ (s, 1H, H2'), 3.31 (dd, $J_{7^{\prime}}$ ', , ' = $6.9 \mathrm{~Hz}, J_{\text {gem }}=9.5 \mathrm{~Hz}, 1 \mathrm{HH} 7^{\prime}$ '), 3.28 (d, J3', ${ }^{\prime}=3.2 \mathrm{~Hz}, 1 \mathrm{H}, \mathrm{H} 3$ '), 2.47 (m, 1H, H6'), 2.19 (m, 1H, H4'), 1.78 (s, 3H, T-Me), 1.37 (s, 3H, 5'-Me), 1.12 (d, $J_{6}$, 6'Me $\left.=6.9 \mathrm{~Hz}, 3 \mathrm{H}, 6{ }^{\prime}-\mathrm{Me}\right) .{ }^{13} \mathrm{C}-$ NMR (125 MHz, $\mathrm{CDCl}_{3}$ ) $\delta: 163.5$ (C4), 149.7 (C2), 138.03, 138.01, 136.9 (C6), 128.6-127.3 (aromatic), 109.4 (C5), 89.7 (C5'), 88.0 (C1'), 77.2 (C3'), 73.1, $70.8\left(\mathrm{CH}_{2} \mathrm{Bn}\right), 68.0$ (C7'), 56.6 (C4'), 49.8 (C2'), 45.5 (C6'), 15.4 (5’Me), 12.4 (T-Me), 8.8 (6'-Me). MALDI-TOF M/S: $[\mathrm{M}+\mathrm{H}]^{+}$found 477.5 , calcd 476.2 .

(1S, 3R, 4R, 5S, 6R, 7S)- 6-(4,4'-Dimethoxytrityloxymethyl)-5-hydroxyl -1,7-dimethyl-3(thymin-1-yl)-2-oxa-bicyclo[2.2.1]heptane (2). To a solution of compound 1 (53 mg, $0.11 \mathrm{mmol})$ in dry methanol $(3 \mathrm{~mL})$ was added $20 \% \mathrm{Pd}(\mathrm{OH})_{2} / \mathrm{C}(168 \mathrm{mg})$ and ammonium formate $(423 \mathrm{mg}, 6.7 \mathrm{mmol}$ ) and reflux for 1.5h. The suspension was filtered over celite bar and organic phase was evaporated. The residue was co-evaporated twice with dry pyridine and dissolved in the same solvent. 4,4'-Dimethoxytrityl chloride (42 mg, $0.12 \mathrm{mmol}$ ) was added and stirred overnight at room temperature. Then the solvent was removed and residue was diluted with DCM, washed with saturated $\mathrm{NaHCO}_{3}$ solution, dried over $\mathrm{MgSO}_{4}$ and subjected to chromatography on silica gel (methanol in dichloromethane containing $1 \%$ pyridine, $0.5-2 \%$, $\mathrm{v} / \mathrm{v}$ ) to give 2 (52 mg, 78\%). ${ }^{1} \mathrm{H}-\mathrm{NMR}\left(500 \mathrm{MHz} \mathrm{CDCl}_{3}\right): \delta 8.92$ (broad, $\left.1 \mathrm{H}, \mathrm{H} 3\right)$, 7.16-7.38 (m, $10 \mathrm{H}), 6.78-6.81(\mathrm{~m}, 4 \mathrm{H}), 5.45\left(\mathrm{~d}, J_{1^{\prime}, 2^{\prime}}=3.0 \mathrm{~Hz}, 1 \mathrm{H}, \mathrm{H} 1^{\prime}\right), 3.52\left(\mathrm{~d}, J_{1^{\prime}, 2^{\prime}}=2.8 \mathrm{~Hz}, 1 \mathrm{H}, \mathrm{H} 1^{\prime}\right), 3.18$ $\left(\mathrm{dd}, J_{7^{\prime}, 4^{\prime}}=6.9 \mathrm{~Hz}, J_{\text {gem }}=9.1 \mathrm{~Hz}, 1 \mathrm{H}, \mathrm{H} 7^{\prime}\right), 3.13-3.09\left(\mathrm{~m}, 2 \mathrm{H}, \mathrm{H} 7^{\prime}, \mathrm{H} 3^{\prime}\right), 2.48$ (m, 1H, H6'), 2.42 (broad, 1H, 3'-OH), 2.09 (m, 1H, H4'), 1.64 (s, 3H, T-Me), 1.55 (s, 3H, 5'-Me), 1.10 (d, J J', 6'Me $=$ $\left.6.9 \mathrm{~Hz}, 3 \mathrm{H}, 6{ }^{\prime}-\mathrm{Me}\right) .{ }^{13} \mathrm{C}-\mathrm{NMR}\left(125 \mathrm{MHz}, \mathrm{CDCl}_{3}\right): \delta 163.7,158.5,144.8,136.2,135.9,130.0$, 129.9, 128.2, 128.1, 127.8, 113.1, 109.8, 90.1, 88.2 (C1'), 86.4, $70.4\left(\mathrm{C} 2^{\prime}\right), 61.9\left(\mathrm{C} 77^{\prime}\right), 58.8$ 
(C4'), 55.2(C3'), $53.0\left(\mathrm{C}^{\prime}\right), 45.0,15.8\left(5^{\prime}-\mathrm{Me}\right), 12.2$ (T-Me), 8.8 (6'-Me). MALDI-TOF $M / S$ : $[\mathrm{M}+\mathrm{Na}]^{+}$found 621.2 , calcd 621.3 .

(1S, 3R, 4R, 5S, 6R, 7S)- 5-(2-(Cyanoethoxy(diisopropylamino)phosphinoxy))-6-(4,4'dimethoxytrityloxymethyl)-1,7-dimethyl-3-(thymin-1-yl)-2-oxa-bicyclo[2.2.1] heptane (3). Compound 2 (51 mg, $0.085 \mathrm{mmol})$ was dissolved in dry THF $(2 \mathrm{~mL})$ and DIPEA $(0.058 \mathrm{~mL}$, $0.34 \mathrm{mmol})$ was added. 2-cynoethyl- $N$, $N$-diisopropyl phosphoramidochloridite $(0.058 \mathrm{ml}$, $0.25 \mathrm{mmol}$ ) was added dropwise to the solution under $\mathrm{N}_{2}$. After stirring of $1 \mathrm{~h}$ at r.t., the reaction was quenched with ethanol and stirred further $10 \mathrm{~min}$. Then diluted with ethyl acetate and washed with saturated $\mathrm{NaHCO}_{3}$ solution, dried over $\mathrm{MgSO}_{4}$ and and subjected to chromatography on silica gel (ethyl acetate in cyclohexane containing $1 \% \mathrm{Et}_{3} \mathrm{~N}, 20-40 \%, \mathrm{v} / \mathrm{v}$ ) to give 2 (54 mg, 72\%). ${ }^{31} \mathrm{P}-\mathrm{NMR}\left(202.5 \mathrm{MHz}, \mathrm{CDCl}_{3}\right)$ : $\delta$ 149.5, 149.3. MALDI-TOF $M / S$ : $[\mathrm{M}+\mathrm{Na}]^{+}$found 799.4 , calcd 798.4.

UV melting experiments. Determination of the $T_{\mathrm{m}}$ of the AON/RNA hybrids or AON/DNA duplex was carried out in the following buffer: $60 \mathrm{mM}$ Tris- $\mathrm{HCl}(\mathrm{pH} 7.5), 60 \mathrm{mM} \mathrm{KCl}, 0.8 \mathrm{mM}$ $\mathrm{MgCl}_{2}$. Absorbance was monitored at $260 \mathrm{~nm}$ in the temperature range from $15{ }^{\circ} \mathrm{C}$ to $70{ }^{\circ} \mathrm{C}$ using an UV spectrophotometer equipped with a Peltier temperature programmer with the heating rate of $1{ }^{\circ} \mathrm{C}$ per minute. Prior to measurements, the samples $(1 \mu \mathrm{M}$ of $\mathrm{AON}$ and $1 \mu \mathrm{M}$ complementary DNA or RNA mixture) were preannealed by heating to $80{ }^{\circ} \mathrm{C}$ for 5 min followed by slow cooling to $20^{\circ} \mathrm{C}$ and $30 \mathrm{~min}$ equilibration at this temperature. The value of $T_{\mathrm{m}}$ is the average of two or three (if error of the first two measurement is more than $0.2{ }^{\circ} \mathrm{C}$, the third measurement was carried out) independent measurements.

CD experiments. CD spectra were recorded from 300 to $200 \mathrm{~nm}$ in $0.2 \mathrm{~cm}$ path length cuvettes. Spectra were obtained with a AON/RNA or AON/DNA duplex concentration of $10 \mu \mathrm{M}$ in $60 \mathrm{mM}$ Tris- $\mathrm{HCl}\left(\mathrm{pH} \mathrm{7.5)}, 60 \mathrm{mM} \mathrm{KCl}, 0.8 \mathrm{mM} \mathrm{MgCl}_{2}\right.$. All the spectra were measured at $20{ }^{\circ} \mathrm{C}$ and each spectrum is an average of 5 experiments from which $\mathrm{CD}$ value of the buffer was subtracted.

${ }^{32} \mathbf{P}$ Labeling of oligonucleotides. The oligoribonucleotides and oligodeoxyribonucleotides were 5 -end labeled with ${ }^{32} \mathrm{P}$ using T4 polynucleotide kinase, $\left[\gamma^{32} \mathrm{P}\right] \mathrm{ATP}$, and the standard protocol. Labeled AONs and the target RNA were purified by QIAquick Nucleotide Removal Kit, and specific activities were measured using a Beckman LS 3801 counter.

RNase H digestion assay. Target $0.1 \mu \mathrm{M}$ RNA (specific activity $80000 \mathrm{cpm}$ ) and a 20-fold

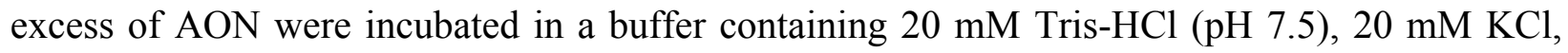
$10 \mathrm{mM} \mathrm{MgCl}_{2}, 0.1 \mathrm{mM}$ EDTA, and $0.1 \mathrm{mM}$ DTT at $21{ }^{\circ} \mathrm{C}$ in the presence of $0.08 \mathrm{U}$ E. coli RNase H. Prior to the addition of the enzyme, reaction components were preannealed in the reaction buffer by heating at $80{ }^{\circ} \mathrm{C}$ for $5 \mathrm{~min}$ followed by slow cooling to $21^{\circ} \mathrm{C}$ and $30 \mathrm{~min}$ equilibration at this temperature. Total reaction volume was $30 \mu \mathrm{L}$. Aliquots of $3 \mu \mathrm{L}$ were 
removed after $3,7,15,25,40$, and $60 \mathrm{~min}$, and the reactions were terminated by mixing with stop solution $(4 \mu \mathrm{L})$ containing $0.05 \mathrm{M}$ EDTA, $0.05 \%(\mathrm{w} / \mathrm{v})$ bromophenol blue, and $0.05 \%(\mathrm{w} / \mathrm{v})$ xylene cyanole in $80 \%$ formamide. The samples were subjected to $20 \% 7 \mathrm{M}$ urea PAGE and visualized by autoradiography.

Stability studies in human serum. AONs at $2 \mu \mathrm{M}$ concentration $\left(5^{\prime}\right.$-end ${ }^{32} \mathrm{P}$ labeled with specific activity $80000 \mathrm{cpm}$ ) were incubated in $30 \mu$ l of human blood serum (male AB) at $21{ }^{\circ} \mathrm{C}$ (total reaction volume was $36 \mu \mathrm{L}$ ). Aliquots $(3 \mu \mathrm{L}$ ) were taken at $0,30 \mathrm{~min}, 1,2,6,8,10,12,24$, $36,48 \mathrm{~h}$, and quenched with $4 \mu \mathrm{L}$ of solution containing $0.05 \mathrm{M} \mathrm{EDTA,} 0.05 \%(\mathrm{w} / \mathrm{v})$ bromophenol blue, and $0.05 \%(\mathrm{w} / \mathrm{v})$ xylene cyanole in $80 \%$ formamide, resolved in $20 \%$ polyacrylamide denaturing ( $7 \mathrm{M}$ urea) gel electrophoresis and visualized by autoradiography.

\section{Acknowledgements}

Generous financial support from the Swedish Natural Science Research Council (Vetenskapsrådet), the Swedish Foundation for Strategic Research (Stiftelsen för Strategisk Forskning), and the EU-FP6 funded RIGHT project (Project no. LSHB-CT-2004-005276) are gratefully acknowledged.

\section{References}

1. Karu, H.; Babu, R.; Maiti, S. Chem. Rev. 2007, 107, 4672.

2. Herdewijn, P. Liebigs Ann. 1996, 1337.

3. Herdewijn, P. Biochimca et Biophysica Acta 1999, 1489, 167.

4. Altona, C.; Sundaralingam, M. J. Am. Chem. Soc. 1972, 94, 8205.

5. Altona, C.; Sundaralingam, M. J. Am. Chem. Soc. 1973, 95, 2333.

6. Thibaudeau, C.; Acharya, P.; Chattopadhyaya, J. Stereoelectronic Effects in Nucleosides and Nucleotides and their Structural Implications; Uppsala University Press, 2005.

7. Isakaaon, J.; Acharya, S.; Barman, J.; Cheruku, P.; Chattopadhyaya, J. Biochemistry 2004, 43, 15996.

8. Kool, E. T. Chem. Rev. 1997, 97, 1473.

9. Manoharan, M. Biochim. Biophys. Acta 1999, 1489, 117.

10. Wengel, J. Acc. Chem. Res. 1999, 32, 301.

11. Morita, K.; Hasegawa, C.; Kaneko, M.; Tsutsumi, S.; Sone, J.; Ishikawa, T.; Imanishi, T.; Koizumi, M. Bioorg. Med. Chem. Lett. 2002, 12, 73.

12. Varghese, O.; Barman, J.; Pathmasiri, W.; Plashkevych, O.; Honcharenko, D.; Chattopadhyaya, J. J. Am. Chem. Soc. 2006, 128, 15173. 
13. Srivastava, P.; Barman, J.; Pathmasiri, W.; Plashkevych, O.; Wenska, M.; Chattopadhyaya, J J. Am. Chem. Soc. 2007, 129, 8362.

14. Albak, N.; Petersen, M.; Nielsen, P. J. Org. Chem. 2006, 71, 7731.

15. Pradeepkumar, P. I.; Cheruku, P.; Plashkevych, O.; Acharya, P.; Gohil, S.; Chattopadhyaya, J. J. Am. Chem. Soc. 2004, 126, 11484.

16. Honcharenko, D.; Varghese, O. P.; Plashkevych, O.; Barman, J.; Chattopadhyaya, J. J. Org. Chem. 2006, 71, 299.

17. Honcharenko, D.; Barman, J.; Varghese, O. P.; Chattopadhyaya, J. Biochemistry 2007, 46, 5635.

18. Koshkin, A. A.; Singh, S. K.; Nielsen, P.; Rajwanshi, V. K.; Kumar, R.; Meldgaard, M.; Olsen, C. E.; Wengel, J. Tetrahedron 1998, 54, 3607.

19. Hunziker, J.; Roth, H. J.; Böhringer, M.; Giger, A.; Didedrichsen, U.; Göbel, M.; Krishnan, R.; Jaun, B.; Leumann, C.; Eschenmoser, A. Helv. Chim. Acta 1993, 76, 259.

20. Augustyns, K.; Vandendriessche, F.; Aerschot, A. V.; Busson, R.; Urbankel, C. H. P. Nucleic Acids Res. 1992, 20, 4711.

21. Aerschot, A. V.; Verheggen, I.; Hendrix, C.; Herdewijn, P. Angew. Chem. Int. Engl. 1995, $34,1338$.

22. Hendrix, C.; Rosemeyer, H.; Bouvere, B. D.; Aerschot, A. V.; Seela, F.; Herdewijn, P. Chem.Eur. J. 1997, 31513.

23. Maurinsh, Y.; Rosemeyer, H.; Esnouf, R.; Medvedovici, A.; Wang, J.; Ceulemans, G. L., E.; Hendrix, C.; Busson, R.; Sandra, P.; Seela, F.; Aerschot, A. V.; Herdewijn, P. Chem.Eur. J. 1999, 5, 2139.

24. Wang, J.; Verbeure, B.; Luyten, I.; Lescrinier, E.; Froeyen, M.; Herdrix, C.; Rosemeyer, H.; Seela, F.; Aerschot, A. V.; Herdewijn, P. J. Am. Chem. Soc. 2000, 122, 8595.

25. Nauwelaerts, K.; Fisher, M.; Froeyen, M.; Lescrinier, E.; Aerschot, A. V.; Xu, D.; Delong, R.; Kang, H.; Juliano, R.; Herdewijn, P. J. Am. Chem. Soc. 2007, 129, 9340.

26. Robeyns, K.; Herdewijn, P.; Meervelt, L. V. J. Am. Chem. Soc. 2008, 130, 1979.

27. Zhou, C.; Liu, Y.; Andaloussi, M.; Badgujar, N.; Plashkevych, O.; Chattopadhyaya, J. J. Org. Chem, 2008; Manuscript ID: jo-2008-016742, first revision submitted to JOC.

28. Zhou, C.; Plashkevych, O.; Liu, Y.; Badgujar, N.; Chattopadhyaya, J. Submitted to Org. Lett. 2008.

29. Zhou, C.; Honcharenko, D.; Chattopadhyaya, J. Org. Biomol. Chem. 2007, 5, 333.

30. Wagner, R. W.; Matteucci, M. D.; Lewis, J. G.; Gutierrez, A. J.; Moulds, C.; Froehler, B. C. Science 1993, 260, 1510.

31. Kurreck, J.; Wyszko, E.; Gillen, C.; Erdmann, V. A. Nucleic Acids Res. 2002, 30, 1911.

32. P., S. J.; Kent, K.; Bird, J.; Fishback, J.; Froehler, B. Nucleic Acids Res. 1991, 19, 747. 